\title{
Ad hoc properties and locations in Maltese
}

\author{
Gréte Dalmi \\ Jan Kochanowski University, Kielce, Poland
}

\begin{abstract}
This paper aims to show that the four-way BE-system of Maltese can best be accommodated in a theory of nonverbal predication that builds on alternative states, without making any reference to the Davidsonian spatiotemporal event variable. The existing theories of non-verbal predicates put the burden of explaining the difference between the ad hoc vs. habitual interpretations either solely on the non-verbal predicate, by postulating an event variable in their lexical layer (see Kratzer 1995; Adger and Ramchand 2003; Magri 2009; Roy 2013), or solely on the copular or non-copular primary predicate, which contains an aspectual operator or an incorporated abstract preposition, responsible for such interpretive differences (Schmitt 2005, Schmitt and Miller 2007, Gallego and Uriagereka 2009, 2011, Marín 2010, Camacho 2012).

The present proposal combines Maienborn's (2003, 2005a,b, 2011) discourse-semantic theory of copular sentences with Richardson's $(2001,2007)$ analysis of non-verbal adjunct predicates in Russian, based on alternative states. Under this combined account, variation between the ad hoc vs. habitual interpretations of nonverbal predicates is derived from the presence or absence of a modal $\mathrm{OP}_{\text {alt }}$ operator that can bind the temporal variable of non-verbal predicates in accessible worlds, in the sense of Kratzer (1991). In the absence of this operator, the temporal variable is bound by the $\mathrm{T}_{0}$ head in the standard way. The proposal extends to non-verbal predicates in copular sentences as well as to argument and adjunct non-verbal predicates in non-copular sentences.
\end{abstract}

Keywords: ad hoc vs. habitual properties, alternative states, accessible worlds, rich structure small clauses, cyclic Agree

\section{Introduction}

This paper ${ }^{1}$ aims to show that the four-way BE-system of Maltese can best be accommodated in a theory of non-verbal predication that builds on alternative states and makes no reference

$\begin{array}{llll} & \text { Abbreviation used in the paper: } & & \\ \text { ABL } & \text { ablative case } & \text { PAST } & \text { past tense } \\ \text { ACC } & \text { accusative } & \text { PiP } & \text { functional category licensing } \\ \text { AP } & \text { adjective phrase } & & {[ \pm \text { pred }],[ \pm \text { obl }],[ \pm \text { phi }] \text { features }} \\ \text { AUX } & \text { auxiliary verb } & \text { PL } & \text { plural } \\ \text { COND } & \text { conditional mood } & \text { POSS } & \text { possessive marker } \\ \text { COP } & \text { copula } & \text { PP } & \text { prepositional phrase }\end{array}$




\section{Problems with the existing accounts of non-verbal predication}

\subsection{Current accounts}

Non-verbal predicates may express either habitual or ad hoc properties in several languages of the world (see Stassen 1996, 2008). In the vast literature on non-verbal predication, this fact is traditionally accounted for by the presence or absence of a Davidsonian spatio-temporal event variable in the lexical layer of non-verbal predicates (Kratzer 1995; Adger and Ramchand 2003; Magri 2009; Roy 2013). ${ }^{4}$ Under these accounts, the italicized non-verbal predicates in (1a) denote a stage-level property (also called ad hoc or actual property), while the italicized non-verbal predicates in (1b) express an individual level (i.e. habitual or permanent) property (examples from Maienborn 2005a):

a. Carol was tired/hungry/angry in the car. $\quad$ (stage-level property)
b. ${ }^{*}$ Carol was blond/intelligent/tall in the car.

The ungrammaticality of (1b) is derived from the absence of the Davidsonian spatio-temporal event variable, which makes spatial anchoring impossible.

The Kratzer-Diesing model, dubbed here as "the event variable-account" has received considerable criticism in recent years (see Maienborn 2003, 2005a,b; Gallego and Uriagereka 2009, 2011 for a list of arguments), the main source of objection being that it excludes variation between the stage-level vs. individual level interpretations of non-verbal predicates that appear in the same syntactic environment (see Doherty 1996 for Irish; Schmitt 2005 for Portuguese; Schmitt and Miller 2007 for Spanish; Richardson 2001, 2007 and Franks 2014 for Russian). Various proposals have been put forward, either to complement or to replace the classic stage-level vs. individual level distinction proposed by Kratzer (1995). Four of these proposal are briefly discussed below, in particular, (i) the scalar implicature-based account; (ii) the P-incorporation account; (iii) the multi-structure account; and (iv) the Kimian state account.

(i) Magri (2009) proposes a scalar implicature-based explanation of the stage-level/individual level contrast. He argues that predicates denoting stage-level properties trigger a scalar implicature (i.e. they entail a set of alternatives), while predicates denoting individual level properties do not tolerate such scalar implicatures and have no alternative set at all.

(2) ${ }^{\star}$ John is sometimes tall.

Thus, the sentence in (2) is claimed to be ungrammatical because no potential alternative states can be associated with it, hence no scalar implicature is triggered.

4 These accounts take the copula to be a semantically empty functional category. Rothstein (2000, 2001), however, provides numerous arguments in support of her claim that the copula does have its own semantic contribution. 
(ii) The ser/estar alternation and its correlation with the semantic interpretation of non-verbal predicates in Spanish copular sentences was already noted by Querido (1976), who suggests the following experiment:

Let us assume that there is a botanist somewhere in the Amazonian jungle who has just discovered a tree of a previously unknown species. The leaves of the tree are yellow. How should he report of his findings in Spanish?

(3) a. Las hojas de este árbol son amarillas.

the leaves of this tree are-s yellow.PL

'The leaves of this tree are yellow.' (ser+habitual property)

b. Las hojas de este árbol están amarillas.

the leaves of this tree are-E yellow.PL

'The leaves of this tree are yellow.' (estar+ad hoc property)

The botanist would be condemned to silence until he finds out whether the predicate amarillas 'yellow.PL' refers to an $a d$ hoc or a habitual property.

(Maienborn 2003: 4-5)

Querido (1976: 354) argues that the difference between ser 'be' vs. estar 'be' should be based on direct vs. indirect evidence.

Gallego and Uriagereka $(2009,2011)$ propose a syntactic P-incorporation account of the ser/estar alternation in Spanish. Although there are a great number of non-verbal predicates that denote either a habitual or an ad hoc property ((4a) vs. (4b)), there are many others that may refer to both in the appropriate context. The non-verbal predicate in (5a)-(5b) is equally correct with ser 'be' and with estar 'be' (examples from Camacho 2012: 453-455):

(4) a. Obama es/está americano.

Obama is-S/is-E American

'Obama is American.' (habitual property)

b. Obama *es/está preocupado.

Obama is-S/is-E worried

'Obama is worried.' (ad hoc property)

(5) a. Alejandro es agradable.

Alejandro is nice

'Alejandro is nice.' (habitual property)

b. Alejandro está agradable.

Alejandro is nice

'Alejandro is nice.' (ad hoc property)

In Gallego and Uriagereka's $(2009,2011)$ model, the ad hoc vs. habitual interpretations are derived from an abstract preposition incorporated in the lexical layer of ser, as a result of which ser gets spelt out as estar:

(6) estar $=\operatorname{ser}+\mathrm{P}($ terminal coincidence $)$ 
The variation between ser and estar is conceived here as the manifestation of inner aspect, i.e. Aktionsart (see Camacho 2012 for details).

(iii) Roy (2013) proposes a three-way system of non-verbal predication: in addition to situation-describing (i.e. stage-level) predicates, she further divides individual level predicates into characterizing and defining ones. She associates the three types of non-verbal predicate with three syntactic categories of different projectional complexity: situation-describing nonverbal predicates project as XPs; characterizing non-verbal predicates are ClPs; finally, defining ones are NumPs. As her "multi-structure" approach draws heavily on the "event variable"-account, it will not be discussed here in detail (see Geist 2014 for a review).

(iv) Maienborn (2003, 2005a,b, 2011) introduces a new ontology of eventualities, arguing that neither type of non-verbal predicate passes the traditional eventuality tests because neither contains a Davidsonian spatio-temporal variable, only a Kimian temporal variable.

(7)

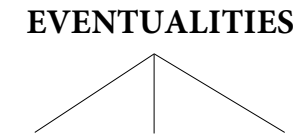

Events Processes D-states [spatio-temporal entities]

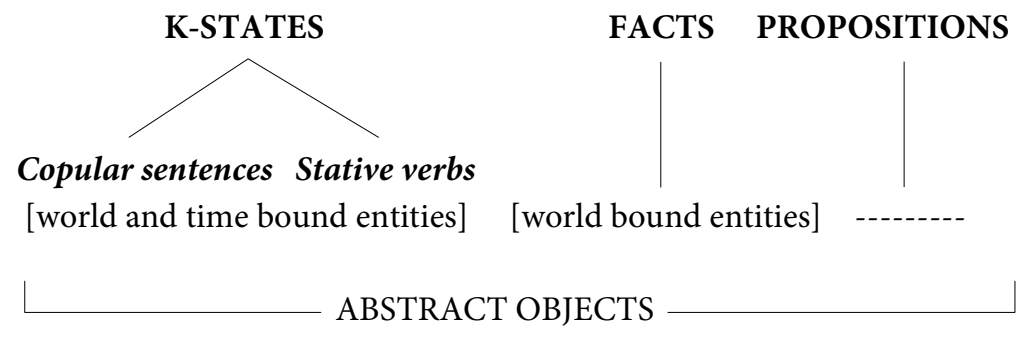

ABSTRACT OBJECTS

In her discourse-semantic account, the interpretation of small clause predicates is determined either by (i) the temporal dimension or (ii) the spatial dimension or (iii) the epistemic dimension of topic situations.

These three dimensions prove insufficient in the case of dream narratives ${ }^{5}$ and noncopular predicates taking adjunct small clauses with the same ambiguity (see Richardson 2001, 2007). Nonetheless, the proposed model, to be explained in detail in section 4, draws on Maienborn's ontology by treating all non-verbal predicates uniformly as Kimian states, i.e.

5 Predicates like dream, imagine, consider, find arguably contain a non-veridical operator and require some oblique case on the non-verbal predicate in several Finno-Ugric languages: while non-verbal predicates appear in Essive in veridical contexts, they bear some other Oblique case (Ablative in Finnish and Dative in Hungarian) in non-veridical contexts (see Fong 2003, and Dalmi 1994, 2002, 2005):

(i) Marij öreg-en $k$ látta ismét az apjátk.

Mary old-Ess saw again the father.POss.ACC

'Maryj saw her fatherk again (when) oldk.'

(ii) Mari túl öreg-nek látta az apját.

Mary too old-DAT saw the father.POss.ACC

'Mary found her father too old.'

(iii) Toini tuli kotiin sairaa-na.

Toini came home ill-Ess

'Toini came home ill.'

(iv) Toini näytää sairaa-lta.

Toini seems ill-ABL

'Toini seems ill.' (modelled on Fong 2003) 
abstract objects denoting a property holding of an $x$ individual at $t$ time. ${ }^{6}$ In contrast to Maienborn's discourse-semantic explanation, the syntactic and semantic differences between non-verbal predicates denoting ad hoc properties/locations vs. habitual properties/locations are derived here from the presence or absence of a modal $\mathrm{OP}_{\text {alt }}$ operator that can bind the temporal variable of Kimian states in accessible worlds in the sense of Kratzer (1991).

\subsection{Some problems}

\subsubsection{The "event variable" account}

It is often noted in the recent syntactic and semantic literature on non-verbal predication that any attempt to derive the ad hoc/actual vs. habitual/characteristic property readings from the presence or absence of the Davidsonian spatio-temporal event variable in the lexical layer of non-verbal predicates will necessarily break down on overlapping contexts, in which both interpretations are acceptable:

(8) a. Alejandro es agradable. (Spanish)

Alejandro is-S nice

'Alejandro is nice (habitual property).'

b. Alejandro está agradable.

Alejandro is-E nice

'Alejandro is nice (ad hoc property).' (Camacho 2012: 453)

(9) a. $B a$ dhochtúir (é) Seán. (Irish)

COP.PAST doctor he.ACC Sean

'Sean was a doctor.' (habitual property)

b. Bhí Sean ina dhochtúir tráth.

AUX.PAST he.NOM PREP doctor once

'He was a doctor once.' (ad hoc property) (Doherty 1996: 39-40)

(10) a. Ivan byl pjan-yj / boln-oj vsju svoju zhizn'. (Russian)

Ivan was drunk-NOM / ill-NOM all his life

'Ivan was drunk/ill all his life.' (habitual property)

b. Ivan byl pjan-ym / boln-ym na proshloj nedel'e.

Ivan was drunk-INST / ill-INST on last week

'Ivan was drunk/ill last week.' (ad hoc property)

(modelled on Richardson 2007: 119)

The presence or absence of the event variable in the non-verbal predicate alone cannot explain the syntactic and semantic differences detected in Spanish, Irish and Russian copular sentences; nor can it account for the so-called "life-time effect" (see Camacho 2012 for Spanish, Doherty1996 for

\footnotetext{
6 Moltmann (2013) proposes a further division of abstract states into atomic and particularized objects. She calls the latter "tropes".
} 
Irish and Richardson 2001, 2007 for Russian). ${ }^{7}$ Furthermore, no correlation with argument and adjunct non-verbal predicates appearing in non-copular sentences can be established.

\subsubsection{The P-incorporation account}

Gallego and Uriagereka $(2009,2011)$ derive the syntactic and semantic differences between ser and estar from an abstract preposition incorporated into the copular predicate. This abstract preposition is responsible for the terminative Aktionsart of estar. At the same time, they also assume a PP projection for all adjectival and participial and locative predicates in copular sentences:

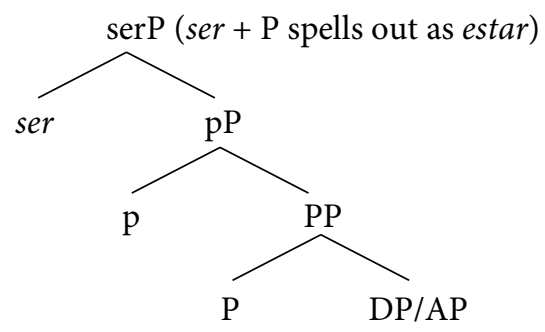

This account rests on the correlation between Spanish locative copular sentences and nominal copular sentences expressing ad hoc properties, the latter of which also require a preposition (see Adger and Ramchand 2003 for a similar reasoning in Scotts Gaelic) and are selected by estar:

Estar with ad hoc properties/locations (examples from Gallego and Uriagereka 2009, 2011)

(12) Doris estaba [AP nerviosa].

Doris was nervous

'Doris was nervous.'

(13) Doris estaba [pp en Bogota].

Doris was in Bogota

'Doris was in Bogota.'

Ser with habitual properties/locations

(14) Doris es mortal.

Doris is mortal

'Doris is mortal.'

(15) Doris es [pp de Bogota].

Doris is from Bogota

'Doris is from Bogota.'

Estar $+P P$ vs. ser $+D P$

(16) Obama está/*es de president desde el 2009.

Obama is of president since 2009

'Obama is (a) president since 2009.'

"Life-time effect": the habitual property reading in past tense copular sentences implies that no change of state can be expected any longer (e.g. because the person is dead) (see Camacho 2012: 459). 
(17) Obama es/*está el president desde el 2009.

Obama is the president since 2009.

'Obama is the president since 2009.'

As will be shown in section 3, Maltese locative copular sentences do not require an overt or abstract preposition of any kind. In the present indicative, they contain merely a zero copula and a definite DP functioning as the locative non-verbal predicate. Such sentences invariably express the habitual/characteristic location of the subject, as in (18). To express the ad hoc/actual location of the subject, the verbal copula qieghed must be used with the same locative DP, as in (19):

(18) It-tabib $0 \quad$ l-isptar. (Maltese)

the-doctor COP the-hospital

'The doctor is at hospital.' (habitual location)

(19) It-tifel qieghed id-dar.

the-boy COP the-house

'The boy is in the house.' (ad hoc location) (Stassen 1996: 280)

The P-incorporation account offers no principled way to predict the interpretive difference between (18) and (19). A minor technical difficulty would also arise by having to incorporate an abstract, null preposition under the zero copula, which, then, gets spelt out as qieghed 'be'. Furthermore, in the Celtic languages (see Doherty 1996 and Roberts 2005), the habitual vs. ad hoc contrast does not hold between two verbal copulas but the pronominal copula BE and the auxiliary BE, as is demonstrated for Irish in (9a-b); in the Semitic languages (see Al-Horais 2006 and Al-Balushi 2011 for Arabic; Shlonsky 2000, 2011 for Hebrew), the same contrast holds between the zero copula and the verbal copula (both of which occur with locatives, though with different interpretations), as is shown in the Standard Arabic examples in (20)-(21):

Standard Arabic copular sentences

(20) Ahmad-u mu'allim-un.

Ahmad-NOM COP.PRES3SG teacher-NOM

'Ahmad is a teacher.' (habitual property)

(21) Ya-kuunu alyaww-u haarr-an ffi Sayfi.

PRES3SG-COP the weather-NOM hot-ACC in summer

'The weather is hot this summer.' (ad hoc property)

(Arabic, Bennamoun 2000: 47, quoted by Al-Horais 2006: 10-103)

It would be difficult to explain this cross-linguistic variation merely by P-incorporation. As such an account has no explanatory power for the zero vs. lexical verb alternation in Maltese and Standard Arabic copular sentences, it will be abandoned for the sake of a combined theory of non-verbal predication that rests on alternative states. 


\subsubsection{The discourse-semantic account}

Maienborn (2003, 2005a,b) offers a whole range of tests in support of the claim that nonverbal predicates have no Davidsonian spatio-temporal event variable, only a Kimian temporal variable. This explains why they pattern alike in the well-known eventuality tests (the ein bisschen 'a little bit' test, the manner adverbial test, the location adverbial test, etc.):

\section{(i) The "little bit" test}

The adverbial modifier ein bisschen 'a little bit' allows for the temporal, the degree, and the eventive readings. With $\mathrm{D}$ (avidsonian)-state predicates such as schlafen 'sleep', stehen 'stand' or liegen 'lie' both the eventive and the degree readings are available, (22). Among predicates denoting K(imian)-states, stage-level predicates support the degree reading but not the eventive reading, (23), while individual-level predicates give bad results both on the eventive and the degree readings, indicating the absence of a spatio-temporal event variable in them, (24) (examples from Maienborn 2003: 11):

D-states: both degree and eventive readings

(22) Das Fenster hat ein bisschen offen gestanden.

the window has a little_bit open stood

'The window stood a little bit open.'

'The window stood open only a little bit.'

K-state expressed by a stage-level predicate: only degree reading

(23) Carol war ein bisschen müde/wütend/hungrig.

Carol was a little_bit tired/angry/hungry

'Carol was a little bit tired/angry/hungry.'

(cf:*'Carol was tired/angry/hungry only a little bit.')

K-state expressed by an individual level predicate: not even degree reading

(24) ${ }^{\star D i e}$ Ampel war ein bisschen gelb.

the traffic light was a little_bit yellow.

'The traffic light was a little bit yellow.'

The fact that neither stage-level nor individual level predicates are compatible with the eventive reading of ein bisschen 'a little bit' supports the claim that the syntactic differences between stage-level vs. individual level predicates cannot be derived from their eventive vs. noneventive nature.

\section{(ii) The manner adverbial test}

Davidsonian eventualities are anchored in space and time. Therefore, they can be modified by manner adverbials. Copular sentences, on the other hand, give bad results with manner adverbials both with stage-level secondary predicates and with individual level secondary predicates, as they do not contain a Davidsonian spatio-temporal event variable (Maienborn 2005a: 294-295): 
(25) *Paul war reglos im Zimmer. Stage-level predicate

Paul was motionlessly in.the room

'Paul was motionlessly in the room.'

(26) ${ }^{*}$ Der Tisch ist stabil aus Holz. Individual level predicate

the table is sturdily of wood

'The table is sturdily wooden.'

Co-variation of stage-level predicates and individual level predicates in grammaticality indicates that anchoring in space is impossible with either of them.

(iii) The locative adverbial test

As Maienborn (2005b: 392) points out, only Davidsonian eventualities can be modified by a VP-internal locative adverbial, Kimian states cannot. ${ }^{8}$ Given that secondary predicates in German must appear in VP-final position, the locative adverbial that precedes the VP-final, adjectival non-verbal predicate in (27) cannot be anything but a VP-modifying PP:

VP-modifying $P P$

(27) ${ }^{*} J o h n[\mathrm{vp}$ ist (gerade) im Schwimmbad fröhlich].

John is at the moment in.the swimming pool happy

'John is (at the moment) in the swimming pool happy.'

The impossibility of adverbial modification by locative PPs signals the lack of the event variable in (27). When the same locative PP is used as a non-verbal predicate and appears in VP-final position, the sentence improves, (28). Here the temporal variable of the Kimian state denoted by the locative PP is bound by the $\mathrm{T}^{0}$ head:

VP-final PP

(28) John_[vp ist (gerade) fröhlich im Schwimmbad].

John is at the moment happy in.the swimming pool

'John is (at the moment) happy in the swimming pool.'

Maienborn (2003, 2005a,b) concludes that the stage-level vs. individual level distinction (Kratzer 1995) cannot be derived from the presence or absence of the spatio-temporal event variable. The reason why neither type of non-verbal (i.e. small clause) predicate passes the eventuality tests is that they denote Kimian states, i.e. they contain a temporal variable but not an event variable. As these tests relate to event structure, they carry over to similar data in other languages without stipulation.

One important reason why Maienborn's theory needs to be complemented is that it does not extend to non-copular sentences. In particular, it does not offer a unified account of argument and adjunct non-verbal predication, as does Richardson's $(2001,2007)$ proposal for Russian non-verbal predicates:

8 Frame-setting and other event-external locative adverbials must be excluded from the range of possible eventuality tests as they are VP-external adjuncts that have no bearing on event structure (see Maienborn 2001). 
(29) Masha vsegda pokupa-et banan-y spel-ye. (Russian)

Masha always buy-PRES3SG banana-PL.ACC ripe-PL.ACC

'Masha always buys bananas ripe.' (habitual situation)

(30) Masha kupi-la banan-y spel-ymi.

Masha buy-PAST.SG.F banana-PL.ACC ripe-PL.INST

'Masha bought the bananas ripe.' (ad hoc situation) (Richardson 2001: 10)

Richardson $(2001,2007)$ claims that Russian speakers use the instrumental case only when they have a set of logically possible alternatives in mind. The sentence in (30) entails alternative states, hence the instrumental case. The nominative case in (29) signals the absence of such entailment. 9 The same case variation is found with motion verbs like priechat' 'to arrive' and vernutsja 'to return' when used with non-verbal adjunct predicates:

(31) Ivan priechal boln-ym no vernulsja domoj zdorov-ym.

Ivan arrived ill-INST but returned home healthy-INST

'Ivan arrived in an ill state but returned in a healthy state.'

(32) Ivan priechal boln-oj i vernuls'a boln-oj.

Ivan arrived ill-NOM and returned ill-NOM

'Ivan arrived in an ill state and returned in an ill state.' (modelled on Richardson 2007: 113)

Motion verbs split eventualities into subevents and can therefore entail alternative states. When the non-verbal predicate bears the instrumental case, it denotes an ad hoc property reached at the endpoint of the eventuality. Nominative case signals that no change of state has taken place between the starting point and the endpoint of the eventuality.

By putting the burden of explanation either solely on the non-verbal predicate or solely on the copula, the existing theories miss a considerable level of generalisation: (i) some of them cannot account for the "overlap cases"; (ii) others cannot explain the "lifetime effect" of non-verbal predicates denoting a habitual property in past tense copular sentences; but most importantly, (iii) almost all of them fail to treat non-verbal argument and adjunct predicates in a uniform way.

If Maienborn's account of non-verbal predicates as 'Kimian states' is complemented with a theory of alternatives (Rooth 1992), we arrive at a unified theory of non-verbal predication in copular and non-copular sentences (see Dalmi 2010a,b,c, 2012, 2013 for a proposal along these lines). Before turning to the combined "alternative state" proposal, let's have a look at the four-way BE-system of Maltese.

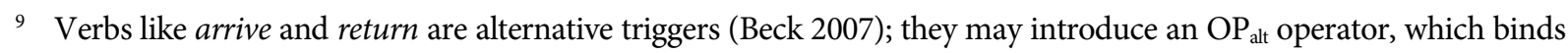
the temporal variable of non-verbal adjunct predicates in accessible worlds (examples from Camacho 2012: 468):

(i) Greta llego contenta/*inteligente.

'Greta arrived happy/*intelligent.'

When a perception verb selects a non-finite clause or a small clause as its complement, it has the direct perception reading (Akmajian 1977). Direct perception restricts the discourse domain to the actual world, hence it excludes the habitual property interpretation:

(ii) Greta vio a Miguel contento/*inteligente.

'Greta saw Miguel in a happy state/*in an intelligent state.' 


\section{The four-way BE-system in Maltese}

Maltese is a Central Semitic Creole, with a particularly rich copular system. In addition to the pronominal copula, it shows the zero vs. lexical copula alternation in the present indicative vs. all other forms of the verbal paradigm. Furthermore, it has two overt verbal copulas, jinsab 'caused to be' and qieghed 'be', both of which are used with non-verbal predicates denoting ad hoc properties or locations. The zero copula is found exclusively in present indicative predicational copular sentences. It readily combines with non-verbal predicates denoting habitual/ characteristic properties:

Maltese (examples from Stassen 1996: 278)
(33) Albert 0/kien tabib.
Albert COP.PRES/PAST doctor.'
'Albert is/was a doctor.'
(34) Albert 0/kien marid.
Albert COP.PRES/PAST sick
'Albert is/was sick.'
(35) Albert 0/kien iddar.
Albert COP.PRES.PAST the-house
'Albert is/was at home.'
(36) It-tabib 0/kien l-isptar.
the-doctor COP.PRES/PAST the-hospital
'The doctor is/was at the hospital.'

If a non-verbal predicate denoting an ad hoc property or location is used with the zero copula, the sentence sounds odd for Maltese speakers (all examples from Stassen 1996):

(37) ??L-istudent $0 \quad$ l-hanut.

the-student COP the-shop

'The student is in the shop.' (??habitual)

The shop is not regarded as a habitual location for students, hence the oddity of the sentence in (37). To express an ad hoc property/location, the verbal copula qieghed 'be' must be used:
(38) Il-vapur qieghed il-port.
the-ship stay.PRES3SG.M the-port
'The ship is in the port.' (temporary, actual)
(39) Pietru qieghed l-eżaminatur.
Peter stay.PRES3SG.M the-examiner
'Peter is the examiner.' (temporary, actual)

By the same token, forcing a non-verbal predicate denoting a habitual property or location to combine with qieghed 'be' leads to ungrammaticality:
(40) ${ }^{\star}$ Malta qieghed-a gzira.
Malta stay-PRES3SG.F island
'Malta is an island.' ( ${ }^{\star}$ temporary, actual)


The pronominal copula is excluded from predicational copular sentences and it does not combine with locative non-verbal predicates, (41)-(42). On the other hand, Borg (1987) notes that the zero copula is always possible in predicational copular sentences, whereas the pronominal copula is restricted to copular sentences with the equative, specificational or identificational interpretations, as in (43)-(45) (Stassen 1996: 289):

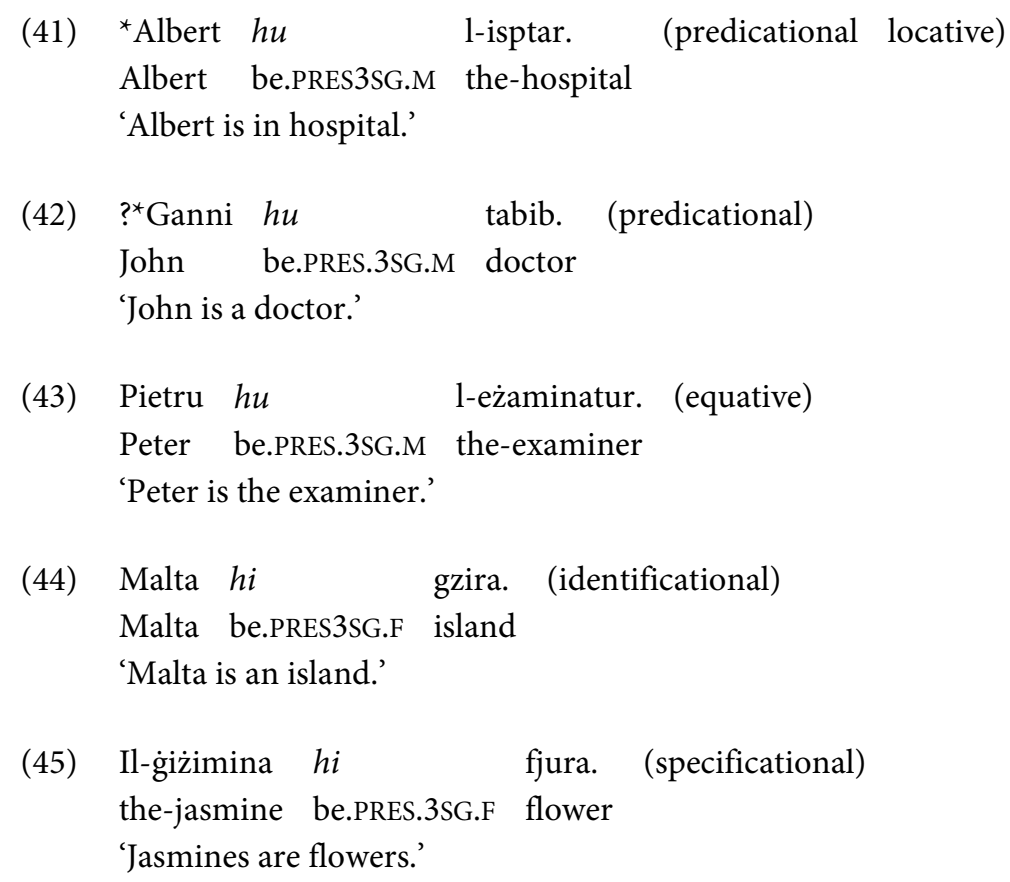

The four-way copular system of Maltese is summarized in (46) and (47). The zero/kien alternation reflects the past vs. non-past division within the verbal paradigm; the zero/pronominal copula alternation is a reflex of the predicational vs. non-predicational interpretations of copular sentences; finally, the zero/qieghed alternation represents the ad hoc vs. habitual contrast (see Stassen 1996, 2008 for details):

(46) Copular sentences in Maltese (Stassen 1996: 290)

$\begin{array}{lcccc}\text { Non-verbal predicate } & \text { ZERO } & \text { JINSAB } & \text { QIEGHED } & \text { PRONOMINAL } \\ \text { Nominal/adjectival } & +(\text { perm }) & + & +(\text { temp }) & + \\ \text { Locative } & + \text { (perm }) & + & +(\text { temp }) & -\end{array}$

(47) The distribution of Maltese copulas in Higgins's typology of copular sentences (based on data from Borg 1987)

Copular sentences
Predicational
Equative
Specificational
Identificational

$\begin{array}{cc}\text { ZERO } & \text { JINSAB } \\ + & + \\ - & - \\ - & - \\ - & -\end{array}$

The proposed model can accommodate the facts of Maltese and at the same time extend to argument and adjunct non-verbal predication without any recourse to the Davidsonian event variable. This makes it more attractive than the existing theories of non-verbal predication. 


\section{An "alternative state"-account without event variables}

\subsection{The proposal}

It is proposed here that the Kimian temporal variable of argument or adjunct non-verbal (i.e. small clause) predicates can be bound in two ways, giving rise to the habitual vs. ad hoc property/location readings, respectively: (i) by the $\mathrm{T}$ (ense) operator above the primary, i.e. verbal, predicate or (ii) by an $\mathrm{OP}_{\text {alt }}$ alternative operator, which takes the whole proposition in its scope and ranges across accessible worlds in the sense of Kratzer (1991). ${ }^{10}$ In the case of (i), no alternative states are entailed and the habitual property reading emerges; in the case of (ii) alternative states are entailed, yielding the ad hoc property reading. This is illustrated in (48a) and $(48 b)$ respectively: ${ }^{11}$

(48)

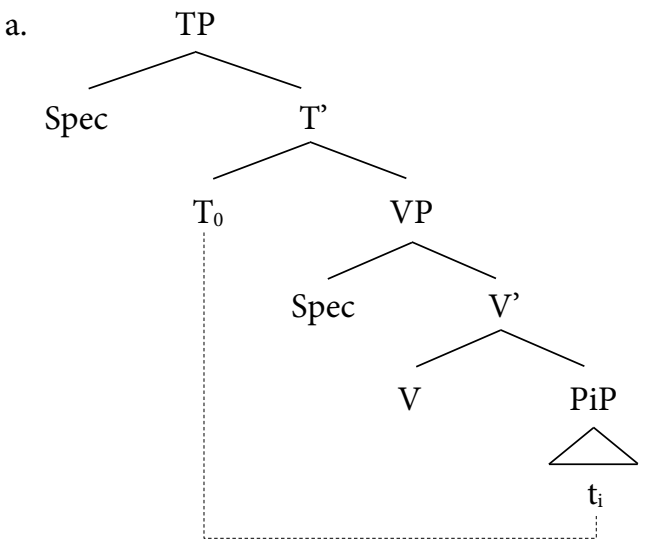

b.

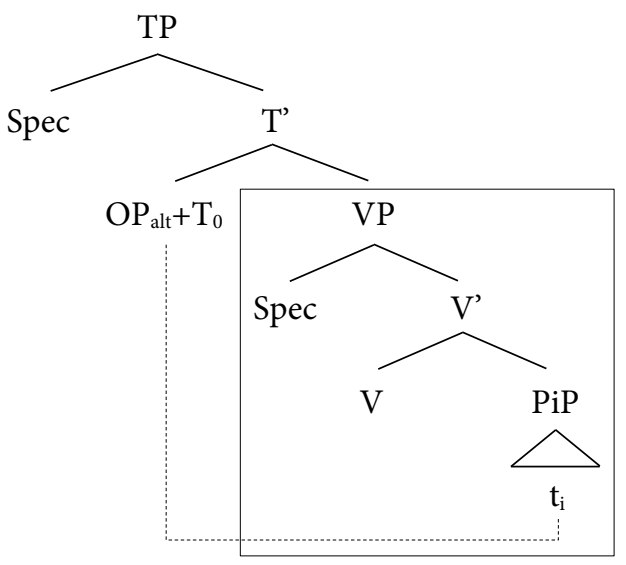

Non-verbal predicates without an alternative state entailment are incompatible with durative adverbials and the episodic operator, (49)-(50). If, however, alternative states are entailed by the primary predicate, the same non-verbal predicate suddenly becomes

10 While the existing accounts of alternative sets (e.g. Beck 2007, Magri 2009) take the ALT or EXH operators to be choice functions, the present proposal views $\mathrm{OP}_{\text {alt }}$ as an intensional operator ranging over accessible worlds, as in Kratzer's (1991) theory of relative modality.

11 On the "rich structure" assumed for all small clauses cross-linguistically, see Dalmi (2010a,b) and section 4.2 of this paper. 
acceptable in modal, conditional and episodic environments, as is demonstrated by the Russian data in (51)-(53): ${ }^{12}$

(49) ${ }^{*}$ Ivan byl vysok-im / inteligentn-im celyj den. (Russian) Ivan was tall-INST / intelligent-INST whole day 'Ivan was tall/intelligent all day.'

(50) ${ }^{\star}$ Ivan byvaet vysok-im / inteligentn-im. Ivan COP.EPS tall-INST / intelligent-INST 'Ivan is (in the habit of being) tall/intelligent.'

(51) Ivan mozhet byt' vysok-im / glu-pym, ja vs'e-taki ljublju ego. Ivan can be.INF tall-INST / dumb-INST I still love.1SG him 'Ivan may well be tall/dumb, I still love him.'

(52) Esli Ivan byl by bolee vysok-im / bolee intelligentn-ym, if Ivan be.PAST COND more tall-INST / more intelligent-INST

ja by vyshla za nego zamuzh.

I COND go.PAST.F for him married

'If Ivan were taller/more intelligent, I would get married with him.'

(53) Ivan inogda byvaet glup-ym.

Ivan sometimes COP.EPS dumb-INST

'Ivan is sometimes dumb.'

The reason for this is that propositions with a modal, conditional, or episodic operator entail the existence of accessible worlds, where alternative states become interpretable.

The structure assumed for sentences containing a non-verbal predicate with the ad hoc property interpretation in Russian is given in (54). ${ }^{13}$ In this structure $\mathrm{OP}_{\text {alt }}$ merges with the $\mathrm{T}_{0}$ head above the VP and binds the temporal variable of the non-verbal predicate within the PiP projection, in accessible worlds:

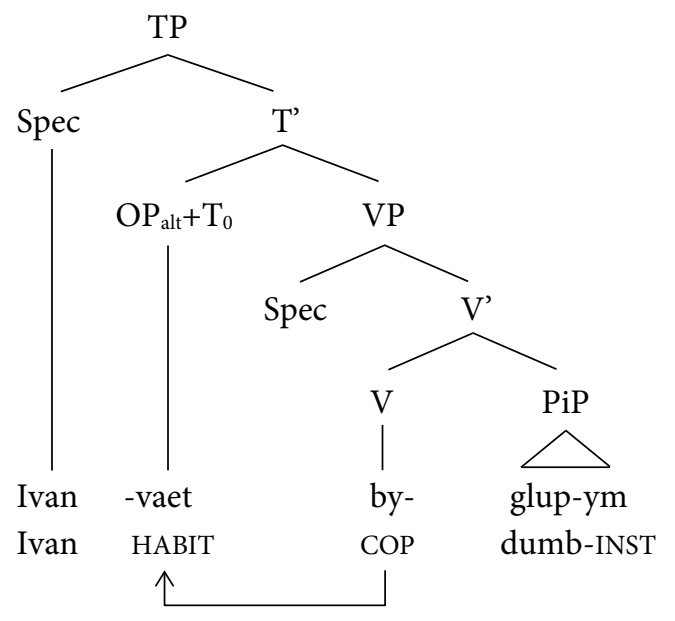

Ivan byvaet glupym.

'Ivan is-EPS dumb.'

12 Unless otherwise indicated, the Russian data were kindly provided and carefully checked by Ekaterina Chernova.

13 Although these semantic tests are demonstrated on Russian data, they are assumed to carry over to other languages. 
The presence of $\mathrm{OP}_{\text {alt }}$ legitimates the instrumental case on the non-verbal predicate and gives rise to the ad hoc property interpretation. Non-verbal predicates denoting inherent properties do not lend themselves to such interpretation. They give ungrammatical results even when combined with primary predicates that normally trigger the alternative state interpretation:

(55) *Ja videla Ivana vysok-ym / inteligentn-ym.

I saw Ivan tall-INST / intelligent-INST

'I saw Ivan (in the state of being) tall/intelligent.'

The zero copula originates as a bundle of syntactic and semantic features under the $\mathrm{V}_{0}$ head (see Al-Balushi 2011 and Dalmi 2010a,b,c, 2013, 2015 for such proposals in Standard Arabic and in Hungarian, respectively). The defective $\mathrm{T}_{0}$ head above the zero copula restricts the domain of conversation to the actual world and therefore cannot combine with $\mathrm{OP}_{\text {alt. }}$ This makes the ad hoc property reading of the non-verbal complement illicit. Thus, the reason why sentences like (56) in Russian are ungrammatical is not the absence of phonological material, as proposed by Pereltsvaig (2007) but rather, the absence of accessible worlds, where alternative states could be interpreted:

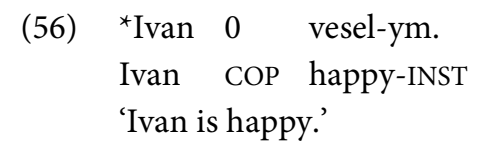

Pronominal copulas lack the $[+\mathrm{V}]$ feature and they do not project a VP at all crosslinguistically; they merely instantiate the abstract tense and agreement features of the predicate (see Al-Balushi 2011; Citko 2008; Eid 1991; Dalmi 2010a,b, 2013, Doherty 1996; Doron 1983, 1986 for similar proposals). When they combine with a non-verbal predicate, their defective $\mathrm{T}$ (ense) restricts the discourse domain to the actual world, excluding alternative states. In the absence of the alternative state entailment, the Kimian temporal variable of non-verbal predicates can only be bound in the actual world; this excludes the ad hoc property reading. ${ }^{14}$

\section{2. "Rich structure" small clauses and Cyclic Agree}

For a combined "alternative state" account to work in multiple BE-system languages, it is necessary to assume a rich structure for all non-verbal predicates. The idea that non-verbal predicates constitute a syntactic unit with their (lexical or null) subject has been present in the generative syntactic literature since Stowell (1981, 1983, 1991). Bowers (1993, 2001) introduces a PredP functional projection for all non-verbal predicates. ${ }^{15}$

In Citko's (2007) account of Polish copular sentences, the $\mathrm{T}_{0}$ head selects a PiP or a PsiP functional category, with either of them surmounting non-verbal predicates (APs, NPs or

\footnotetext{
${ }^{14}$ See Bailyn (2011) for a critical review of the syntactic accounts of the zero/lexical verb variation in Russian copular sentences, and Partee and Borschev (2007) for a discourse-semantic analysis of the same.

${ }^{15}$ See Pereltsvaig (2007) for a structural account of the interpretive differences found in Russian copular sentences; see den Dikken (2006), Dalmi (2010b, c), and Bondaruk (2013) for arguments against her account.
} 
PPs). In particular, if the $\mathrm{T}^{0}$ head is not filled by any lexical item, it selects a PiP; if it is filled by the pronominal copula, it selects a PsiP. The PiP projection hosts case and phi features compatible only with the verbal copula; PsiP has case and phi features which enable it to combine with the pronominal or the dual copula.

Citko (2007) assumes that the $\mathrm{Pi}_{0}$ head licenses instrumental case on nominal predicates and nominative case on adjectival predicates; $\mathrm{Psi}_{0}$ can license only nominative case and phi features on non-verbal predicates. Another property that distinguishes these two functional projections is that the pronominal copula is merged under the $\mathrm{T}_{0}$ head, i.e. it remains outside the PsiP functional projection, while the verbal copula is part of PiP, yielding a mono-clausal copular construction (see Dalmi 2010a,b,c, 2013 and Bondaruk 2013 for two alternative approaches, respectively):

a. Verbal copular sentence

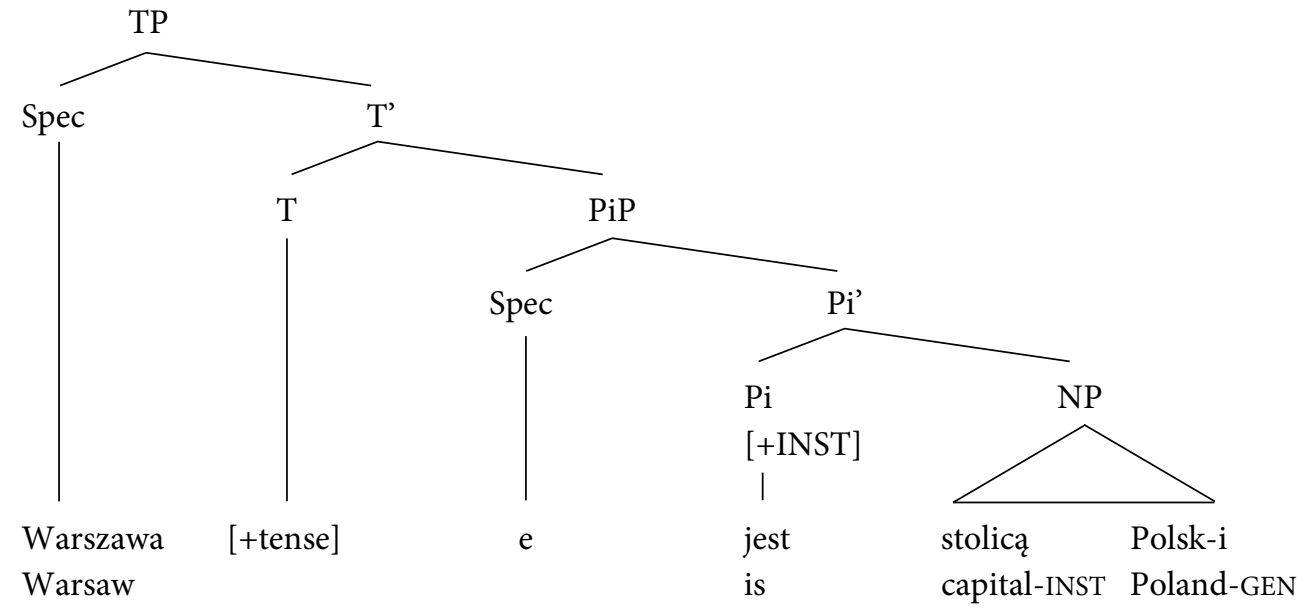

'Warsaw is the capital of Poland.'

b. Pronominal copular sentence

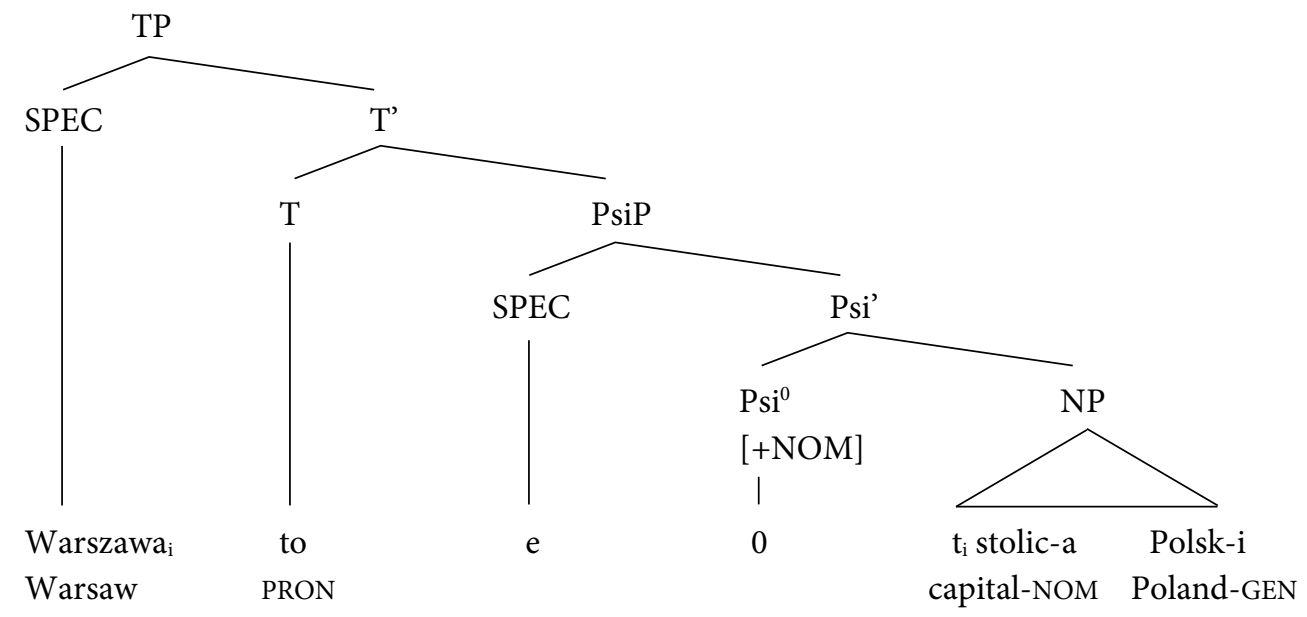

Though later Citko (2008) modifies her proposal and assumes a PiP of two kinds, an eventive one and a non-eventive one, this correlation is preserved. Although the present proposal draws on her original "rich structure" model, it does not adopt the "lexical selection" explanation (see Dalmi 2010b,c for details). 
In the model assumed here (in line with Dalmi 2010a,b,c, 2013, 2015), the copula+nonverbal predicate combination emerges from a "rich structure" small clause, surmounted by a defective lexical layer (the so-called V-domain), a functional layer (the T-domain) and a richly articulated C-domain in the sense of Rizzi (1997, 2004, 2013). This Raising-type structure is necessary in order to maintain a uniform concept of predication relation (see Bowers 1993, 2001, Stowell 1981, 1983 and 1991 for details).

Unlike existential BE-predicates that take a theme and a location argument (see Partee and Borschev 2007 for Russian and Błaszczak and Geist 2001 for a comparison of Russian and Polish), copular BE-predicates are monadic unaccusatives that select merely a small clause complement (like all the other Raising verbs, seem, appear, and become): ${ }^{16}$

(58) $\quad \mathrm{BE}_{\mathrm{COP}} \quad<\mathrm{PiP}>$

[+pred]

In the course of the derivation, the subject and the non-verbal predicate will have their features checked/probed overtly or covertly by the relevant functional head. In contrast to Citko's $(2007,2008)$ analysis, the present proposal assumes that both PiP and PsiP are the extended projections of the non-verbal predicate; they project within the "rich structure" of the non-verbal predicate simultaneously, hence there is no c-selection by the copula: ${ }^{17}$

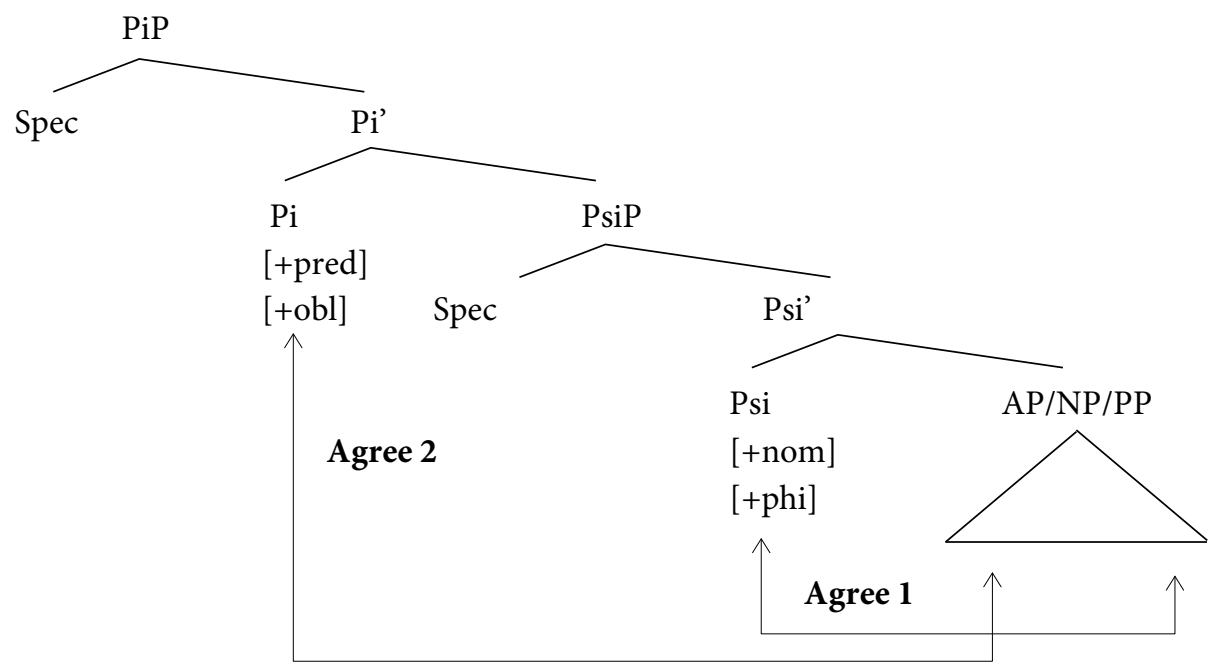

The mechanism of Cyclic Agree, originally proposed by Bèjar and Rezac (2009) to treat the agreement facts of Basque double object constructions, enables non-verbal predicates to have their features checked/probed via partial Match. This machinery has proved useful for a number of unrelated phenomena and it also seems to be crucial for languages in which nonverbal predicates bear case. Cyclic Agree is realized by space extension: the search space is

\footnotetext{
16 See Heycock $(1994,2012)$, Heycock \& Kroch (1998) for a similar view.

17 Citko's $(2007,2008)$ mono-clausal account is problematic for a number of reasons listed by Dalmi (2010b,c).

Those relevant for the present discussion are repeated here:

i. predication relation is not treated in a uniform way;

ii. finite and non-finite copular constructions need to be assigned different structures;

iii. cross-linguistic ad hoc/habitual variation cannot be accommodated.
} 
extended to the next functional category if the relevant features cannot be fully licensed by the nearest one (see Bèjar and Rezac 2009 for details).

In a structure like (59), non-verbal predicates can have their [+pred], [+case] and [+phi] features licensed by the corresponding functional head in two steps. The PsiP projection is involved in licensing nominative case and phi features, while the $\mathrm{PiP}$ projection licenses predication and oblique case..$^{18}$ Although this licensing process takes place in cycles, the exact nature of its realisation is conditional on the presence or absence of the $\mathrm{OP}_{\text {alt }}$ operator in the $\mathrm{T}$-domain of primary predicates. Thus, $[+\mathrm{obl}]$ is licensed in $\mathrm{PiP}$ only if $\mathrm{OP}_{\text {alt }}$ is present in the T-domain; in all other cases, all features are licensed in canonical ways.

\subsection{Ad hoc properties and locations: the connection}

The reason why Maltese is particularly interesting for a theory of non-verbal predication is that it shows a four-way split of the copular system along the past vs. non-past, the ad hoc vs. habitual, the locative/non-locative and the predicational vs. non-predicational axes. Maltese speakers use non-verbal predicates with the zero copula to describe habitual properties/locations. The overt verbal copulas jinsab and quieghed are used with non-verbal predicates to refer to ad hoc properties/locations. The pronominal copula lacks the [+V] feature required by $\mathrm{OP}_{\text {alt }}$ and this excludes the ad hoc interpretation of the non-verbal predicate that it combines with. ${ }^{19}$

What non-verbal predicates denoting ad hoc properties and locations have in common cross-linguistically is that both of them entail alternative states. Certain primary predicates may act as alternative triggers in the sense of Beck (2007). With such primary predicates, the $\mathrm{OP}_{\text {alt }}$ operator binds the temporal variable of the non-verbal predicate in accessible worlds. This gives rise to the ad hoc property interpretation of the non-verbal predicate. In the absence of such alternative triggers, the $\mathrm{T}_{0}$ head alone binds the temporal variable of the nonverbal predicate in the actual world and the habitual reading emerges.

The proposed mechanism extends to non-verbal predicates in copular and non-copular sentences, can explain the life-time effect and can incorporate the facts of Maltese. The $\mathrm{OP}_{\text {alt }}$ alternative operator qualifies in non-veridical contexts (e.g. in dream narratives) as it ranges over accessible worlds; therefore the "alternative state" account offers wider empirical coverage than the existing accounts do.

\footnotetext{
17 The Revised Predication Licensing Principle (RPLP) (Dalmi 2005: 95) is given as follows:

Predication relation is syntactically realized by the [+pred] feature, and must be licensed on the left edge of the functional layer (TP, AgrP or PiP) in each clause.

19 This provides independent evidence for locating the pronominal copula under the T0 head crosslinguistically, see Doherty (1996) for Irish, Eid (1991) for Arabic, Doron (1983, 1986) for Hebrew and Citko (2007, 2008) for Polish. The zero copular predicate is the null head of the VP projection (see Fassi-Fehri (1993) for Arabic, Partee (1998) for Russian and Dalmi (2010b,c; 2013) for Hungarian).
} 


\section{Summary}

The paper argues that the four-way copular system of Maltese, a Central Semitic Creole, can be best accommodated in a theory of non-verbal predication that builds on alternative states. Neither the "event variable" account, nor the P-incorporation account can adequately capture the syntactic and semantic differences between non-verbal predicates denoting ad hoc vs. habitual properties. The proposed model combines Maienborn's (2003, 2005a,b) analysis of copular construction with a theory of alternatives states. This ensures that argument and adjunct non-verbal predicates in copular and non-copular sentences receive a uniform treatment.

\section{References}

Adger, D., and Ramchand G. 2003. Predication and equation. Linguistic Inquiry 34: 325-360.

Akmajian, A. 1977. The complement structure of perception verbs in an Autonomous Syntax Framework. In P. Culicover, T. Wasow, and A. Akmajian (eds.), Formal Syntax, 427-460. New York: Academic Press.

Al-Balushi, R. 2012. Why verbless sentences in Standard Arabic are verbless? Canadian Journal of Linguistics 57(1): $1-30$.

Al-Horais, N. 2006. Arabic verbless sentences: Is there a null VP? Pragmalinguistica 14: 101-116.

Bailyn, J. 2011. The syntax of Russian. Cambridge: Cambridge University Press.

Beck, S. 2007. The grammar of focus interpretation. In H-M. Gärtner, and U. Sauerland (eds.), Interfaces+Recursion=Language?Chomsky's Minimalism and the view from syntax/semantics, 255-280. Berlin: Mouton.

Bèjar, S., and M. Rezac. 2009. Cyclic Agree. Linguistic Inquiry 40: 35-73.

Bennamoun, E. 2000. The featural structure of functional categories: A comparative study of Arabic dialects. Oxford: Oxford University Press.

Błaszczak, J., and L. Geist. 2001. Zur Rolle des Pronomens to/eto in specificierenden Kopulakonstruktionen im Polnishen und Russischen [To the role of to/eto in specificational copular constructions in Polish and Russian]. In G. Zybatow, U. Junghanns, G. Mehlhorn, and Szucsich (eds.), Current Issues in Formal Slavic Linguistics (= Linguistik International 5). 247-257. Frankfurt am Main: Peter Lang.

Bondaruk, A. 2013. Copular clauses in English and Polish. Structure, derivation and interpretation. Lublin: Wydawnictwo KUL.

Borg, A. J. 1987. To be or not to be a copula in Maltese? Journal of Maltese Linguistics 17/18: 54-71.

Bowers, J. 1993. The syntax of predication. Linguistic Inquiry 24: 591-656.

Bowers, J. 2001. Predication. In M. Baltin, and C. Collins (eds.), The handbook of contemporary syntactic theory, 299-333. Oxford: Blackwell.

Carlson, G. 1980. Reference to kinds in English. New York: Garland.

Camacho, J. 2012. Ser and Estar: The individual/stage level distinction and aspectual predication. In J.I. Hualde, A. Olarrea, and E. O'Rourk. (eds.), The handbook of Hispanic linguistics, 453-475. Oxford: Blackwell.

Citko, B. 2007. Small clauses: Not so small and not all alike. Ms. www.ling.auf.net

Citko, B. 2008. Small clauses: Not so small and not all alike. Lingua 118: 261-295.

Dalmi, G. 1994. Hungarian infinitival constructions. M.Phil. diss., Sydney, The University of Sydney.

Dalmi, G. 2002. The role of AgrP in non-finite predication. Ph.D. diss. Budapest, Eötvös Loránd University.

Dalmi, G. 2005. The role of agreement in non-finite predication. Linguistik Aktuell 90. Amsterdam: John Benjamins.

Dalmi, G. 2010a. Copular sentences, K-states and secondary predication. Talk given at STALDAC. Cambridge, Newnham College.

Dalmi, G. 2010b. Copular sentences, predication and cyclic Agree. A comparative approach. Saarbrücken: Lambert Academic Publishing (VDM). 
Dalmi, G. 2010c. Copular sentences, predication and cyclic Agree. Habilitation Treatise, Budapest, Eötvös Loránd University.

Dalmi, G. 2012. Copular sentences expressing Kimian states in Irish and Russian. Canadian Journal of Linguistics 57(3): 341-358.

Dalmi, G. 2013. The meaning of the zero copula in multiple BE-system languages. In A. Bondaruk and A. Malicka-Kleparska (eds.), Ambiguity. Multifaceted structures in syntax, morphology and phonology. Studies in Linguistics and Methodology (SLAM) Vol. 5, 169-201. Lublin: Wydawnictwo KUL.

Dalmi, G. 2015. What does it take to be a copula? Talk given at PLM 45 Poznań.

Davidson, D. 1980. The logical form of action sentences: Criticism, comment, and defence. In D. Davidson (ed.), Essays on Actions and Events, 101-148. Oxford: Clarendon Press.

Dikken den, M. 2006. Relators and Linkers. Cambridge, MA: MIT Press.

Doherty, C. 1996. Clausal structure and the Modern Irish copula. Natural Language and Linguistic Theory 14:146.

Doron, E. 1983. Verbless predicates in Hebrew. Ph.D. diss., Austin, University of Texas.

Doron, E. 1986. The pronominal copula as agreement clitic. In H. Borer (ed.), The syntax of pronominal clitics, 313-332. New York: Academic Press.

Eid, M.1991. Verbless sentences in Arabic and Hebrew. In B. Comrie, and M. Eid (eds.), Perspectives on Arabic linguistics. Current Issues in Linguistic Theory 80. 31-61. Amsterdam: John Benjamins.

Fassi-Fehri, A. 1993. Issues in the structure of Arabic clauses and words. Dordrecht: Kluwer.

Fong, V. 2003. Resultatives and depictives in Finnish. In S. Manninen, and D. Nelson (eds.), Generative approaches to Finnic and Saami linguistics. 201-235. Stanford: CSLI.

Franks, S. 2014. The overgeneration problem and the case of semipredicatives in Russian. In A. Bondaruk, G. Dalmi, and A. Grosu (eds.), Advances in the Syntax of DPs. Structure, agreement, and case. Linguistik Aktuell 217, 13-60. Amsterdam: John Benjamins.

Gallego, A., and J. Uriagereka. 2009. Estar $=$ Ser + P. Paper presented at the XIXth Colloquium on Generative Grammar. Vitoria-Gasteiz. Basque Country.

Gallego, A., and J. Uriagereka. 2011. The lexical syntax of ser and estar. Ms. Universitat Autonoma de Barcelona and University of Maryland.

Geist, L. 2014. Review of "Non-Verbal Predication: Copular Sentences and the Syntax/Semantics Interface" by I. Roy. Journal of Linguistics 50: 255-260.

Heycock, C. 1994. The internal structure of small clauses: New evidence from inversion. Proceedings of NELS 25: 222-238.

Heycock C. 2012. Specification, equation and agreement in copular sentences. Canadian Journal of Linguistics 57.2: 209-240.

Heycock, C., and A. Kroch. 1998. Inversion and equation in copular sentences. In A. Alexiadou, N. Fuhrhop, U. Kleinhenz, and P. Law (eds.), ZAS Papers In Linguistics 10: 71-87. Berlin: Zentrum für Allgemeine Sprachwissenschaft.

Kratzer, A.1991. Modality. In A.von Stechow, and D. Wunderlich (eds.), Semantics. An international handbook of contemporary research, 639-650. New York: Mouton de Gruyter.

Kratzer, A. 1995. Stage-level and individual level predicates. In G. Carlson, and F. Pelletier (eds.), The generic book, 125-176. Chicago: The University of Chicago Press.

Kratzer, A. 2012. What must and can must and can mean. In A. Kratzer (ed.), Modals and conditionals. New and revised perspectives, 1-21. Oxford: Oxford University Press.

Magri, G. 2009. A theory of individual level predicates based on blind mandatory scalar implicatures. Natural Language Semantics 17: 245-297.

Maienborn, C. 2001. On the position and interpretation of locative modifiers. Natural Language Semantics 9: 191-240.

Maienborn, C. 2003. Against a Davidsonian analysis of copular sentences. In M. Kadowaki, and S. Kadahara (eds.), Proceedings of NELS 33: 167-186.

Maienborn, C. 2005a. On the limits of the Davidsonian approach: The case of copular sentences. Theoretical Linguistics 31.3: 275-316. 
Maienborn, C. 2005b. A discourse-based account of Spanish ser/estar. Linguistics 43(1):155-180.

Maienborn, C. 2011. Event semantics. In C. Maienborn, K.von Heusinger, and P. Portner (eds.), An international handbook of natural language meaning. Volume 1, 803-829. Berlin: Mouton de Gruyter.

Marín, R. 2010. Spanish adjectives within bounds. In P. Cabredo-Hoffher, and O, Matushansky (eds.), Adjectives: Formal analyses in syntax and semantics. Linguistik Aktuell 153, 307-332. Amsterdam: John Benjamins.

Moltmann, F. 2013. On the distinction between abstract states, concrete states and tropes. In C. Beyssade, A. Mari, and F. del Prete (eds.), Genericity, 293-312. Oxford: Oxford University Press.

Partee, B. 1998. Copular inversion puzzles in English and Russian. In K. Dziwirek, H. Coats, and C. Vakareliyska (eds.), Formal Approaches to Slavic Linguistics, 361-395. Ann Arbor: Michigan Slavic Publications.

Partee, B., and Borschev, V. 2007. Existential sentences, BE and GEN NEG in Russian. In I. Comorowski, and Karl von Heusinger (eds.), Existence: Semantics and syntax, 147-191. New York: Springer.

Pereltsvaig, A. 2007. Copular sentences in Russian. A theory of intra-clausal relations. New York: Springer.

Querido, A. 1976. The semantics of copular constructions in Portuguese. In M. Lujan, and F. Hensey (eds.), Current studies in RomancelLinguistics, 343-366. Washington: Georgetown University Press.

Richardson, K. 2001. What secondary predicates in Russian tell us about the link between Tense, Aspect and Case. In Niina Zhang (ed.), ZAS Papers in Linguistics 26: 1-25.

Richardson, K. 2007. Case and Aspect in Slavic. Oxford: Oxford University Press.

Rizzi, L. 1997. The fine structure of the left periphery. In L. Haegeman (ed.), Elements of grammar, 281-337. Dordrecht: Kluwer.

Rizzi, L. 2004. On the cartography of syntactic structures. In L. Rizzi (ed.), The Structure of CP and IP. The cartography of syntactic structures, volume 2, 3-17. Oxford: Oxford University Press.

Rizzi, L. 2013. Topic, focus and the cartography of the left periphery. In S. Luragi, and C. Parodi (eds.), The Bloomsbury companion to syntax, 436-451. London: Bloomsbury.

Roy, I. 2013. Non-verbal predication: Copular sentences at the syntax/semantics interface. Oxford: Oxford University Press.

Rooth, M. 1992. A theory of focus interpretation. Natural Language Semantics 1: 75-116.

Rothstein, S. 2000. Fine-grained structure in the eventuality domain: The semantics of predicative adjectival phrases and BE. Natural Language Semantics 7: 347-420.

Rothstein, S. 2001. Predicates and their Subjects. Dordrecht: Kluwer.

Schmitt, C. 2005. Semi-copulas. Event and aspectual composition. In I. Kempchinsky, and R. Slabakova (eds.), Aspectual Inquiries, 121-145. New York: Springer.

Schmitt, C., and K. Miller. 2007. Making discourse-dependent decisions: The case of the copulas ser and estar in Spanish. Lingua 117: 1907-1929.

Shlonsky, U. 2000. Subject positions and copular constructions. In H. Bennis, M. Everaert, and E. Reuland (eds.), Interface strategies, 325-347. Amsterdam: Royal Netherlands Academy of Arts and Sciences.

Shlonsky, U. 2011. Hebrew as a partial null subject language. Studia Linguistica 63(1): 133-157.

Stassen, L. 1996. The switcher's paradise: Nonverbal predication in Maltese. Rivista di Linguistica 8(1): 275-300.

Stassen, L. 2008. Zero copula for predicate nominals. In M. Haspelmath, M. Dryer, D. Gil, and B. Comrie (eds.), World atlas of language structures online. Chapter 120. Munich: Max Plank Digital Library. http://www.wals.info

Stowell, T. 1981. The origin of phrase structure. Ph.D. diss., Cambridge, MA: MIT Press.

Stowell, T. 1983. Subjects across categories. The Linguistic Review 2: 285-312.

Stowell, T. 1991. Small clause restructuring. In R. Freidin (ed.), Principles and parameters in comparative grammar, 183-218. Cambridge, MA: MIT Press. 